CE uS-W orking Paper no. 2001/ 7

\title{
SOCIAL BENCHMARKING, POLICY-MAKING AND NEW GOVERNANCE IN THE EU
}

Caroline de la Porte, Philippe Pochet, G raham Room

Jean Monnet Centre for E uropean Studies (CE uS)

University of Bremen

SFG , Enrique-Schmidt-Strasse 7

D - 28359 Bremen

Phone +49 - 421 - 218-9037

Fax $+49-421-218-9143$

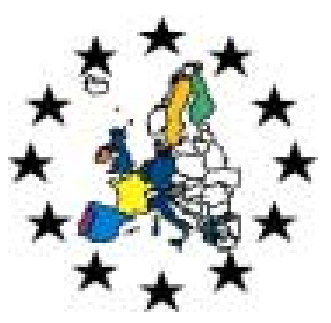



CE uS-W orking Paper no. 2001/ 7

\section{SOCIAL BENCHMARKING, POLICY-MAKING AND NEW GOVERNANCE IN THE EU}

Caroline de la Porte, Philippe Pochet, Graham Room

Caroline D elaporte and Philippe Pochet are at the Observatoire social européen (OSE) in Brussels; G raham Room is Professor of European Social Policy at the University of Bath. 



\title{
SOCIAL BENCHMARKING, POLICY-MAKING AND NEW GOVERNANCE IN THE EU1
}

\author{
Caroline de la Porte, Philippe Pochet, Graham Room*
}

\begin{abstract}
ABST RACT
The European Union has established an "open method of coordination" (OMC) among the Member States, as a means of pursuing economic and employment growth, coupled with greater social cohesion. The paper analyses the assumptions underlying this strategy, the manner of its operation and its implications for policy learning and for governance. It argues that the OMC has in substantial measure been inspired by the experience of EMU, but that this is a perilous paradigm on which to base social benchmarking and the OMC. Second, it argues that the dynamic development of the OMC will depend crucially on the extent of public involvement in scrutinising the policy areas which political leaders choose for benchmarking, the best practices which they identify in other Member States, and the efforts which they then make to improve national performance. The conclusion is that the $\mathrm{OMC}$ is likely to have substantial implications for domestic and European governance, but that these could be very different, depending on the manner of its implementation. Finally, the paper considers the implications of the analysis for the broader theoretical literature.
\end{abstract}

Keywords: Benchmarking, EU policy-making, governance, social indicators, policy learning

1 Forthcoming, Journal of E uropean Social Policy, Vol 11 no 4 (November 2001)

* The authors are grateful to Leonello Tronti for his helpful comments on drafts of this paper, along with other participants at the seminar $\mathrm{N}$ ew $\mathrm{G}$ overnance Process in the E U, organised by the Observatoire social européen in Brussels in July 2000. They are also grateful for comments received from anonymous referees of the Journal of E uropean Social Policy. The OSE research was supported by the Belgian Ministry of Social Affairs, but does not necessarily represent the view of that Ministry. 


\section{Introduction}

During the Lisbon Summit of March 2000, the European Union (EU) set itself the goal of becoming "the most competitive and dynamic knowledge-based economy in the world, capable of sustainable economic growth with more and better jobs and greater social cohesion". To reach this strategic aim, the open method of coordination (OMC), a de-centralised but carefully coordinated process, has been established. This article addresses some of the questions raised by this method of coordination, as well as its policy implications. What are the tools and processes associated with OMC? How can the frameworks to which it is applied be differentiated? And in what degree does OMC introduce changes to the governance of the EU? The paper retraces the precursors and principal sources of influences on $\mathrm{OMC}$, notably monetary union and the European Employment Strategy, using these as points of comparison for the social benchmarking that has evolved since the Lisbon Summit. It considers the implications of social benchmarking and policy co-ordination for policy learning and EU governance in general. It concludes that the OMC is likely to have substantial implications for domestic and European governance, but that these could be very different, depending on the manner of its implementation.

Several lines of theoretical discussion, in the wider academic literature, are of particular interest for the argument of the paper. First, the OMC is a form of policy coordination, albeit within a polity endowed with a variety of intergovernmental and supranational modes of decision-making, and can therefore be viewed by reference to the substantial literature on policy coordination. Second, it can also be related to the literature on organisational learning, cross-national policy transfer and lesson-drawing. Third, the international relations literature has studied the institutional conditions for securing international cooperation and the strategies which national and sub-national actors can pursue within this institutional arena. Finally, there is a growing theoretical literature on the governance of supranational and international institutions. It is to these broader discussions that we turn in the final section of the paper. 


\section{The instruments of "new governance": benchmarking and the open method of coordination}

\subsection{Benchmarking}

A benchmark is defined as "a standard or point of reference against which things may be compared or assessed" (Pearsall, 1999: 125). Benchmarks must be chosen by reference to the objectives of an organisation, whether it is commercial or public. This is because benchmarking is a tool by which an organisation assesses how well it is meeting its objectives and how they could be met even more effectively. More specifically, benchmarking involves comparing how an organisation is doing relative to its pers. It is therefore most obviously done by reference to organisations which have identical, or at least similar, objectives. However, even where the objectives are similar, benchmarking risks ignoring differences in the context of the organisations being compared. Lessondrawing based principally on benchmarking is therefore hazardous (Lundvall and Tomlinson, 2001).

Benchmarking can be initiated by the organisation itself ('bottom-up'), or it can be imposed from above and outside ('top-down'). The former involves searching for best practices, organisational learning and continuous improvement in order to eliminate performance gaps. The latter, in contrast, involves a variety of quality assurance policies and the dissemination of findings in order to improve performance across the sector (Tronti, 1998: 10.1.1.1-10.1.1.3). The former allows each organisation to choose those benchmarks which are appropriate to its own specific objectives; the latter assumes that all the organisational units in question have the same objectives, and can be scrutinised by reference to the same benchmarks.

\subsection{Benchmarking Social E urope: The Open Method of Coordination (OMC)}

The use of benchmarking as "an instrument to promote change and continuous improvement of Europe's competitive performance" was developed in 1996, with the Communication "Benchmarking the Competitiveness of European Industry" (CEC, 1996) and in 1997 with the Communication "Benchmarking: Implementation of an instrument 
available to economic actors and public authorities" (CEC, 1997). This built upon work by the Round Table of European Industrialists (ERT, 1996).

During the European Council of Lisbon, in March 2000, benchmarking became part of a more complex and comprehensive strategy, the OMC, introduced to promote the development of the knowledge-based economy, in tandem with increased social cohesion and employment (Council of the European Union, 2000: 4). It was emphasised that OMC should be conceived as a "learning process for all", which should respect national diversity and should not be seen as a competition in the overall context of adapting to the global context. OMC has its own logic and can be seen as a compromise between a logic of pure integration and a logic of simple cooperation.

The conclusions of the Lisbon Council stipulate that the new open method of coordination is a means of spreading best practice and of achieving thereby greater convergence. It involves:

- fixing guidelines for the Union, combined with specific timetables for achieving the goals which they set in the short, medium and long terms;

- establishing, where appropriate, quantitative and qualitative indicators and benchmarks against the best in the world and tailored to the needs of different Member States and sectors, as a means of comparing best practice;

- translating these European guidelines into national and regional policies by setting specific targets and adopting measures, taking into account national and regional differences;

- periodic monitoring, evaluation and peer review, organised as mutual learning processes (European Council, 2000).

In this process, the Commission is meant to play a co-ordinating role, by presenting proposals on the European guidelines, organising the exchange of best practices, presenting proposals on potential indicators, and providing support to the processes of implementation and peer review (This in turn raises the important question of the new balance of power between the intergovernmental and supranational players in the EU: however, this is beyond the scope of the present paper). 
In the documents emanating from the Council and the Commission, $\mathrm{OMC}$ is conceived as an instrument for deepening European integration, in conjunction with other instruments, ranging from harmonisation to loose cooperation. The overall aim is to organise a European level process of acquiring knowledge, with a view to encouraging Member States to exchange best practices and to learn from them, so as to improve their own national policies (Council of the European Union, 2000: 5). The development of organised and reciprocal learning processes to cope with the key stakes of a rapidly changing world is at the heart of the method. While OMC has recourse to benchmarking, it goes beyond this by defining European level guidelines and identifying common challenges, even if the formulation of the response to the challenges remains the responsibility of Member States.

The Council and the Commission also intend that OMC should involve all the relevant stakeholders: the Union, the Member States, the local and regional collectivities, as well as the social partners and civil society. It is also meant to improve transparency and deepen democratic participation, one of the key objectives of the European Union, as indicated in the work programme of the forthcoming White Paper on European Governance.

The dominant discourse on the OMC presents it as the ideal application of the subsidiarity principle, in the framework of which the European level plays a minor role. However, upon deeper analysis, this complementarity between OMC and subsidiarity is less clear. Whereas subsidiarity defines the level of power that is the most appropriate for each sphere of action, OMC recognises the interrelation between different spheres, promoting interaction between different levels of power and spheres of action. Moreover, the principle of subsidiarity is often associated with the principle of proximity, according to which decisions should be taken as close as possible to the grass-roots level, while OMC underlines the need to proceed via a widely meshed interactive process, in which the actors - ranging from European to local level - have to articulate their strategy and actions in a multi-level logic (see Pochet, 2001). 


\section{Application of the instruments of new govemance to different policy areas}

\subsection{The Precursors}

We will now consider how OMC, benchmarking and the other instruments of new governance are being interpreted and applied in selected policy areas. However, it is first worth noticing their most important precursors, in the fields of monetary and employment policy.

\section{Monetary Union}

Under the terms of the Treaty on European Union, the drive for monetary union involved a set of common objectives to "ensure sustained convergence of the economic performances of Member States" (article 99 TEU), with benchmarks of fiscal and monetary performance, to be attained as a precondition of EMU membership and then to be maintained. Under the terms of the Stability and Growth Pact of 1996, monetary sovereignty is pooled and in regards to their overall fiscal balances, countries are accountable to multilateral surveillance and supranational governance, with financial sanctions attached. Indeed, each Member State of the euro zone has been required to submit a three-year convergence programme, to be examined by the Commission and by its peers. To support this process, the broad economic policy guidelines set out priorities and recommendations for the euro-zone as a whole as well as more specifically for each Member State. Financial sanctions have only been foreseen in the case of non-compliance with the ceiling rate of a $3 \%$ budget deficit fixed by the Council. Sanctions for noncompliance with other objectives or recommendations - such as the reduction of the global public debt - take the form of pressure by peers, the financial markets and public opinion.

However, before taking this as the benchmark by reference to which other benchmarking exercises can be judged, the distinctive features of this monetary regime must be noted. Most obviously, it was achieved under German monetary hegemony: the governance of their anchor currency would henceforth be pooled, but according to benchmarks and disciplines that the German monetary authorities would primarily define. Whether or not a coherent system of benchmarking can or should be attempted in other 
fields, in the absence of a hegemonic power or coalition, is a question that will be discussed below. It is also important to notice that even while a common monetary regime was imposed, the institutional contexts of the various countries differed, as did the economic, political and institutional changes that were required, in order to attain the monetary benchmarks. Thus, for example, the development of national social pacts proved particularly important for those countries which faced difficulty in sustaining the new monetary regime (Fajertag and Pochet, 2000). The benchmarks may have been uniform, but the consequences of their application for the different countries concerned were very different.

At least two additional lessons can be drawn from the EMU process. First of all, national adaptations to the common regime were made due to the pressures for convergence upon national systems and elites. This pressure is transposable to other contexts, and is notably one of the driving forces behind the employment strategy. Secondly, the political and bureaucratic elites have not hesitated to use EMU as a pretext (vinolo esterno is the term used by Dyson and Featherstone, 1996) to make politically sensitive changes that would otherwise have been too difficult to implement. Indeed, Europe has been considered as a valuable political resource to legitimise change (Ferrera and Gualmini, 1999).

\section{Employment and the Luxembourg Process}

It was in considerable measure as a "spillover" from these difficulties in adapting to the monetary and fiscal demands of EMU that concerted action to address persisting problems of unemployment was accepted as a political imperative during the mid-1990s. A first attempt to define the contours of a European Employment Strategy was made during the European Council of Essen (D ecember 1994). After its failure, mainly due to the absence of a control process (peer review), a second attempt was made during the intergovernmental conference, leading to the signature of the Amsterdam treaty (1997) and its employment chapter. The underlying logic consisted of mimicking the EMU process. This included the institutional set-up: an employment committee, with an advisory role for the Labour and Social Affairs Council, was created to counterbalance the economic policy committee, which advises the Ecofin Council. Thus the benchmark of the employment 
strategy was EMU: the key difference was the lack of sanctions in case of non-compliance (Goetschy and Pochet, 1997).

The process is based on guidelines that provide a margin for adaptation at national level, but which also involve a process of benchmarking, multilateral surveillance and peer review. Member States are encouraged to transpose the specific policy objectives in the Employment Guidelines to national level programmes in regard to their particular socioeconomic circumstances. To illustrate their efforts, they submit an annual report. The Commission and the Labour and Social Affairs Council in turn synthesise the national reports and make an annual assessment of progress overall, as well as of the individual Member States. In this light, the Labour and Social Affairs Council adapts the guidelines, issues recommendations to Member States and decides upon new initiatives at Community level. This process is repeated on an annual basis, becoming a governance process in its own right: something that helps to explain why it has been spreading to other policy areas, in the framework of the open method of coordination (G oetschy,1999).

The process has not been tension-free. Indeed, although the European Employment Guidelines or recommendations issued to specific Member States do not have a binding character, the yearly categorisation of the performance of each country individually has proved to be an uncomfortable finger-pointing session, putting pressure on the Member States to converge towards the benchmark that has been selected as the ideal goal to achieve. In order to improve their respective situations in the overall competition, some countries need to implement structural reforms, which are not necessarily in tune with their dominant national policy objectives or traditions.

Therefore, even if there has been a political resurgence of social democracy across the EU Member States, it has been no easy matter to find sufficient agreement on common objectives and guidelines for this benchmarking exercise. Still less has there been consensus on the policy measures to be undertaken. This is, of course, a general question in relation to benchmarking: the benchmark may be agreed, but not the means to pursue it. In contrast to the monetary area, there is in the case of employment policy no hegemon to issue definitive rulings, nor indeed are there explicit sanctions to enforce compliance (although the political opprobrium that attaches to those who do not play according to the rules of the game can be very powerful). 
However, even in the absence of hegemony, it has been possible for the Member States to agree upon some common objectives. One of these agreed objectives is to reach an overall employment rate of 70\% (and 60\% for women) by 2010, something which is likely to have a particularly strong impact on the conservative welfare states. Another objective, diffused throughout the European Employment Guidelines, is to attain a new balance between individual and collective responsibility in employment and unemployment (Bonvin and Burnay, 2000). Nothing is said about how to achieve these two goals. Nevertheless, what is striking, as indicated by Scharpf (2000), is the overwhelming agreement on the employment guidelines, despite the wide spectrum of national employment policies across the Union, ranging from the solidarity-orientated policies in France (Tholoniat, 2000) to the individualist policies in the United Kingdom (Kenner, 1999). Agreement has been possible partly because the quantitative objectives were initially very general and broad, enabling them to win common support from the Member States. An additional explanation could be the voluntary, technical and "depoliticised" logic of the approach, where one of the principal objectives has been to launch a learning process and trust-building among the players involved (2).

\subsection{Social Benchmarking after the Lisbon Summit}

Benchmarking in the social field is still more recent, having been set in motion - in its most recent version - during the Lisbon Summit (2000). We need to recall why the benchmarking of social policies within the $\mathrm{EU}$ has been raised at all. It is primarily because, against the background of the integration of monetary policy and the close coordination of macro-economic policy, along with a general commitment to promoting supply-side policies for flexibility and employability, national and EU authorities have recognised the need to work together on policies for social cohesion. This recognition is driven partly by political factors: pressure from the trade unions in face of the deflationary impact of EMU and the political goals of the left-of-centre governments that now dominate the EU. It is, equally, driven by recognition of the linkages between economic, monetary and labour market policies on the one hand, and employment, social protection and social cohesion

2. In some of the background documents prepared by experts for the Commission, these "technical" procedures have been elaborated in the form of the "radar charts" familiar in the benchmarking literature of the commercial world: see, for example, Tronti (1998); Mosley and Mayer (1998). However, this approach seems now to be going out of favour with the Commission. 
policies on the other: the latter cannot be left to be managed at national level alone, given their consequences for the former.

\section{Social Protection}

Social protection has come a long way since the two Council recommendations of 1992, the first aiming at a convergence of social protection, the second at a definition of sufficient resources in social assistance systems (Council of the European Union, 1992a, 1992b). The method of implementation proposed at the time resembles a premature version of OMC, consisting of regular reporting on the steps taken in the Member States, measured according to appropriate criteria, agreed upon with the Member States: five years later, however, there was no hint of any progress in the formulation of a common method (CEC, 1999). Nevertheless, the 1995, 1997 and 1999 communications on social protection, particularly the latter, have progressively raised social protection on the European agenda, and have contributed positively to a common understanding of European social protection (de la Porte, 1999a), something that is a prerequisite for effective benchmarking. The turning point was the strong politically-orientated four-pillar objective set out in the 1999 social protection communication, aiming at concerted improvement in all Member States in the areas of employment (to make work pay), poverty and social exclusion, pensions and health care.

In justifying the need for the European Union to intervene in the area of social protection, explicit reference is made to EMU and to the employment strategy, which are considered as ideal models of European institutional coordination. A social protection committee, reminiscent of the employment committee, was set up during the Finnish Presidency at the end of 1999, endowed with the task of activating the social protection strategy. It was thereafter formalised during the Nice Summit, and was integrated into the Treaty (article 144). In the socially-orientated political atmosphere after Lisbon, the longterm aim was to draw up European guidelines for social protection, which would be implemented in the same manner as the Employment Guidelines. The strategy would involve strengthening cooperation in the field of social protection to meet common challenges; setting common objectives that are ambitious and realistic, using clear indicators whenever possible; ensuring the necessary flexibility for Member States to be 
able to implement their respective policies; and closer cooperation among Member States, based on the exchange of experience and best practice.

However, this programme is far from being realised. The principal reason is that Member States fear an intrusion of the European Union into their national arrangements. In the Nice Treaty, the Heads of State and Government therefore stipulated that the EU policies "shall not affect the right of Member States to define the fundamental principles of their social security systems and must not significantly affect the financial equilibrium thereof" (article 144). Another reason is that the comparative statistics on social protection which are available, for example through the European System of Integrated Social Protection Statistics (Esspros), provide a general but rather unclear picture of the social protection patterns throughout the EU. It is only now that the weaknesses and gaps of these systems as valid comparative instruments are being seriously analysed (CEC, 2000a). There is also the problem that definitions of social protection vary according to national context, even if it is generally agreed that statutory, occupational and fiscal schemes should all be included (Berghman, 1997) and account should be taken of mandatory private spending, direct taxation on social transfers, indirect taxation on consumption of social services and fiscal advantages accorded to certain disadvantaged groups (Adema, 1998).

The fundamental difficulty lies in the differences in conception and arrangement of the welfare state among the EU fifteen, with national social protection systems being embedded within specific institutional structures (Berghman, 1997; Ferrera et al., 2000). In contrast to the sphere of monetary policy, here there is no hegemon capable of enforcing a single vision of social objectives. Some social objectives can, it is true, be argued by reference to the imperatives of the single market, but these rarely have sufficient precision to silence debate. Policy objectives remain in considerable measure a matter for the national authorities, even if their sovereignty and autonomy in social policy have been constrained (Leibfried and Pierson, 1995). The contrast with the monetary field is therefore even more marked than in the case of employment policy.

Given this situation, the instrument that has in practice been prioritised is that of dialogue: cooperation rather than coordination is under way. This involves the exchange of views that is supposed to be beneficial to all Member States; but there are no common objectives, no guidelines, no recommendations, no peer review, no sanctions. In the field 
of pensions it has been decided to apply the $\mathrm{OMC}$, but it remains to be seen what benchmarks can be agreed (Math and Pochet, forthcoming 2001/2). What is striking, moreover, is the institutional competition between the Economic Policy, Social Protection and Employment Committees, and the corresponding Councils and Directorates-G eneral of the Commission, to shape the agenda of pension coordination and benchmarking.

\section{Poverty and Social Exclusion}

Notwithstanding these difficulties, poverty and social exclusion have been singled out as a quasi-separate area of action and as a common challenge for Europe. The promotion of social inclusion is to be carried out through the OMC. D uring the French Presidency, the objectives were defined and endorsed by the Nice European Council. The strategy consists of promoting participation in employment and providing access to resources, rights, goods and services for all European citizens, preventing the risks of exclusion and helping the most vulnerable (Labour and Social Affairs Council, 2000). The strategy also involves integrating the solidarity principle into Member States' employment, education and training, health and housing policies ("mainstreaming") and defining priority actions for specific target groups (such as minorities, children, the aged and people with disabilities). The choice of the most appropriate actions remains in the hands of the Member States.

Taking these objectives into account, each Member State was required by June 2001 to present a national action plan to combat poverty and social exclusion, including the national level indicators that have been selected to take account of the multi-dimensionality of the phenomenon, and to measure progress in relation to national and regional targets and the overall European objectives. Peer review and supranational monitoring and evaluation are an integral part of the exercise, creating pressure to converge towards European level objectives. The exercise is to be repeated on a bi-annual basis.

The most sensitive issue is the establishment of commonly agreed indicators. The social protection committee has been seeking to define clearer long-term policy objectives and indicators for monitoring the situation (de la Porte, 1999b: 33). As in the case of the employment strategy, benchmarks will include performance indicators (comparison with the average of the best performers among the EU) and policy indicators (measuring the degree of effort carried out by individual Member States). As in the case of social 
protection more generally, however, weaknesses and gaps in existing systems of comparative statistics will need to be addressed, requiring improved analysis of the characteristics, causes, processes and development of social exclusion. Although efforts are being made to improve the quality of the data, new and relevant data will only be available in a few years.

The official documents emphasised that the fight against social exclusion is the primary responsibility of Member States and of their national, regional and local authorities. The Community Action Programme which was proposed in 2000 is conceived as being an element of added value to these national level activities, in order to activate and enhance the exchange of information and best practices among Member States (CEC, 2000b). Rather than financing some isolated projects, as was formerly the case, the programme will support coordinated research efforts, especially concerning the definition of common indicators, networking and structural financing of representative organisations (CEC, 2000b: 4-5). The role of the Community level is also to support evaluation and monitoring by peers, which is intended to produce a mutual exchange of lessons, while the Council is important in setting the overall objectives for actions to combat poverty.

Finally, the fight against social exclusion is to take place through an integrated approach, based on partnerships, the participation of all those concerned and by promotion of processes of individual reintegration at the micro-level. This is turn explains the central role given to dialogue and the exchange of information and best practices, to be stimulated by the organisation of colloquia, meetings and networks, organised in collaboration with the Presidency of the Union (CEC, 2000b: 4-5).

\section{Policy Leaming and Govemance}

The foregoing discussion poses two questions fundamental for theorising EU policymaking. First, what is the relationship between policy learning and policy coordination: how far does the former depend upon agreed objectives for the latter? Second, what are the implications for processes of governance? In addressing both of these questions, we seek to expose the theoretical and policy dilemmas which social benchmarking poses. 


\subsection{Social Benchmarking, Coordination and Policy Learning}

We have contrasted coordination in the monetary, employment and social fields, in terms of the strong hegemonic role played in the former by the German monetary authorities. The objectives and benchmarks which they defined and the political leverage they were able to bring to the process of monetary unification drove out dissent, with the political classes in each of the aspirant members of Euroland subordinating other policy interests to this one overriding national objective.

In the employment and, even more, in the social field, there is, we have argued, no such hegemon, enforcing a single vision of the challenges which confront the EU Member States. That assertion is not strictly correct. The very success of monetary policy coordination now poses its own threat to social benchmarking: hegemonic spill-over from those actors whose own political legitimacy has been reinforced by monetary union. The Ecofin Council and the Economic Policy Committee in particular have been attempting to influence the definition of benchmarks across the different sectors with which the Lisbon Summit was concerned (Ecofin Council, 2000; and EPC, 2000). Not only does this risk imposing, as ostensible technical necessities, common social objectives which override national political choices: it risks doing so on terms that privilege fiscal discipline over social needs and social cohesion. To this extent, the 'technical' character of current benchmarking processes in the social field, while it may serve to build trust and stronger forms of concertation, risks doing so in an arena which obscures the social political choices at stake. To contest this hegemony of fiscal discipline, however, is to accept that no coherent social vision is currently available: on the contrary, the legacy of diverse welfare regimes makes for significantly different visions, embedded in different institutional and political domestic settlements.

Where does this leave European social benchmarking? Where there are no common objectives, or where those that are enunciated are so loose as to be almost meaningless, does it follow that no benchmarking is possible? As noted earlier, benchmarking in many cases arises, bottom-up, as the initiative of a particular organisation, eager to assess and to better its performance. This is most obviously the case with a commercial enterprise, benchmarking its competitors and using their best performance as the standard by which to judge itself. However, individual countries can also do this. In the case of social policy, 
therefore, each EU member state might benchmark other Member States by reference to its own policies. This would exploit the value of benchmarking as a tool for raising standards of performance, while at the same time recognising the diversity of national policy objectives.

Such bottom-up benchmarking could still involve a role for the EU institutions. Although nationally-driven, bottom-up benchmarking might nevertheless involve the cycle of $\mathrm{EU}$ reporting and peer review that already characterises $\mathrm{OMC}$ in the area of social exclusion Moreover, the EU institutions - in particular the European Commission - could play a technical role in ensuring that the Member States had available to them information about best practice in each other's territories; and they could ensure that these information resources were organised in an efficient manner, to avoid duplication of effort. Finally, the Commission could offer expert commentary on the national reports and facilitate peer review. The value of this bottom-up benchmarking would also be enhanced if the EU institutions were to strengthen learning capacity across the Community in respect of policy innovation and improvement. The various programmes of cross-national innovation and policy learning that the Commission has long supported in the social field provide a number of models on which this capacity-building could build (Room, 1986,1993).

This is, arguably, the approach to social benchmarking that is being adopted in the aftermath of the Nice Summit, for example in relation to social exclusion and poverty. Nevertheless, bottom-up benchmarking and cross-national policy learning, to be effective, need to be driven to a substantial extent by the policy actors in the individual countries concerned. Coordination here must involve decentralised learning networks rather than the hegemonic imposition of a monolithic discipline. National governments and other actors at national level - professional and practitioner networks, policy evaluation think-tanks, training organisations for social actors - have a key role to play: not so much as guardians of national sovereignty, checking that the principle of subsidiarity is not infringed, but rather as interpreters between sub-national actors and organisations on the one hand, the array of good (and bad) practices across the other Member States on the other hand. 


\subsection{Social Benchmarking and Governance}

EMU and the European Employment Strategy were the precursors of the open method of coordination and EU social benchmarking. However, their implementation also highlighted fundamental questions of EU governance. Monetary union, which we have taken as the purest case of supranational coordination, was itself dependent on an agreement by Member States to adopt a common policy objective: the hegemony of the German monetary authorities would have had little substance but for that political commitment by governments (Woolley, 1992). However, this sort of commitment requires heroic acts of political leadership by the countries concerned. In the case of monetary union, the economic promise suggested by the paradigmatic German case was vital for political leaders' efforts to maintain popular acquiescence in a period of austere public finances. So attractive was this promise, that it enabled these leaders to lock their countries into long-term commitments to monetary discipline, embodied in the Maastricht Treaty, from which it would be exceedingly difficult and costly to extricate themselves.

However, the political commitment to EMU generated a renewed debate about EU governance in a rapidly changing world. The European Union has recognised that it is urgent to develop a common understanding of governance in the EU: hence the timeliness of the forthcoming White Paper on Govemance, one of whose aims is to promote new forms of European governance (CEC, 2000c). The soft processes involved in OMC, emphasising transparency, accountability and effectiveness, would seem to have an obvious relevance to principles of good governance. OMC also seems well-attuned to the currently fashionable debates on "multi-level governance", with the actions of independent public actors at different levels articulated with each other to reach shared objectives.

We have pointed to some of the ways in which, even in the social field, the Member States have sought to move to certain common objectives. This also raises important questions of governance. This is, not least, because the development of OMC has been accompanied by various forms of resistance and tension among the actors involved. The recommendations made by the Commission to Member States are sometimes resented, and the Commission is in some instances seen as putting pressure on Member States to follow a specific policy line. Public scrutiny and debate are likely to be crucial, if processes of

policy cooperation and coordination in the social field are to be politically feasible. Without 
this national democratic debate, some players could and would use Europe as a scapegoat to implement politically sensitive changes at national level, as was the case for EMU. Moreover, where there is little or no scope for scrutiny and critical debate, the reporting by national authorities to the EU institutions can become extraordinarily anodyne. This can lead to the whole process of performance monitoring and reporting being discredited. As Scharpf (2000, p.xxx) argues in relation to the employment strategy: "the danger is that the 'National Action Plan' will merely restate what governments are doing anyway, and that the learning effect of deliberations at European level may only educate international 'liaison' officials who lack effective power at home". The challenge is how to reconcile diversity and democratic accountability, on the one hand, with convergence and efficiency, on the other hand.

We have argued that even where there are no common social objectives, nationallydriven, bottom-up benchmarking could be a useful vehicle for cross-national policy learning. It is therefore important to consider what would be the implications of processes such as these for national and EU governance. This question can be addressed by considering what sanctions and incentives could be attached to this process of bottom-up social benchmarking. At one level, these sanctions would be similar to those in the case of employment policy: countries which fail to meet the benchmarks - and they would after all be benchmarks which they had themselves chosen - would be subject to the moral censure of their fellow governments. However, at least as important would be the degree of involvement of the domestic constituencies of each national government in enforcing sanctions and rewards. "Good governance" would mean a high degree of involvement for the public in scrutinising the policy areas which political leaders choose for benchmarking, the best practices which they identify in other Member States, and the efforts which they then make to improve national performance. Indicators, targets and procedures would not be imposed from outside or from above, but debated more openly. Under such scrutiny, domestic political leaders - in government or opposition - would no longer be able to rely on the relative ignorance of their population regarding practices elsewhere: they would, instead, need to justify their own performance by comparison with best practice in other countries. Social benchmarking of the sort envisaged here would then have crucial consequences for their political credibility. 
If, even without agreement on specific common objectives, 'bottom-up' social benchmarking of this sort were to be made obligatory, along with processes of public scrutiny and debate, this would constitute a powerful commitment to good governance on the part of the EU. This is, at least in embryo, what the OMC involves. It would do more than this, however: for while it would affirm national responsibility, it would also affirm Community interest in how that national responsibility is exercised. Even where there are no major and demonstrable consequences of national policies for other Member States or for other areas of Community policy, the Community is recognised as having an interest in good governance for all citizens of the Union. This raises profound questions as to the nature of the EU as a supranational political community.

It could also have consequences for the political credibility of the EU itself. It was suggested earlier that to rush into social benchmarking by reference to common objectives which are only vague or illusory could risk the whole exercise being discredited, not least in the eyes of the populations of the various EU countries. In contrast, social benchmarking of the sort envisaged here would promote better domestic governance, as a return on the investment which countries make in European collaboration. This could provide the means which political leaders require, in order to demonstrate eloquently to their populations the positive benefits of European integration.

Such a demonstration could in turn, indeed, enable a move to greater agreement on common objectives, and hence to social coordination, and not just cooperation, through the OMC. This is consistent with Biagi's argument in relation to the sphere of employment: "Consistent application of the Luxembourg exercise might lead to a convergence of Member States' employment policies, not dictated by Brussels but based on growing consensus on effective solutions through a process of trial and error" (Biagi, 2000: 159). Thus, even where, in contrast to monetary union, the "pressures for convergence" coming from above are only weak, the 'pressures for accountability' coming from below, as the fruit of the building of good governance, may serve to sustain the pace of cross-national policy learning through the OMC. 


\section{Conclusion}

The EU, acting as a 'semi-sovereign' policy system, "seems slowly but surely to be carving out for itself a distinct co-ordinating role in a number of social policy areas - a role that can work to rebalance 'softly' and 'from below' the structural asymmetry between negative and positive integration" (Ferrera et al., 2000: 65). The OMC can be characterised as a "post-regulatory" approach to governance, in which there is a preference for procedures or general standards with wide margins for variation, rather than detailed and non-flexible (legally binding) rules. It is by intensive consultation, mainly among Member State representatives, that standards - non-rigid in that they are adapted to different institutional arrangements, legal regimes and national contexts - are set and modified (Mosher, 2000). The term "vertical decentralisation" - a supple application of rules by players at the appropriate level, according to local contexts (CEC, 2000d: 6) - captures the essence of the process. In addition to the suppleness in the spatial dimension, there is also considerable malleability in the temporal dimension, in that Member States can move at different speeds in reforming policy.

The areas to which the OMC is applied - including social inclusion - are ones which were traditionally thorny, not only in the sense of being jealously protected, as matters of national sovereignty, but also as being areas where effective policies can only with difficulty be devised. The OMC, it may be argued, is alert to both of these issues: it avoids centralised supranational governance, so that it can cater appropriately for national diversity, and it "institutionalises the sharing of Member States' experiences with reform experiments." (Mosher, 2000, p.xxx) Nevertheless, the analysis in this paper reveals that matters are not quite so simple. This has implications both for the practical politics of the $\mathrm{OMC}$ and for its theorisation.

\subsection{The Practical Politics of Social Benchmarking and the OMC}

First, we have argued that recent moves to policy coordination, including the OMC, have in substantial measure been inspired by the experience of EMU. However, this is a perilous paradigm on which to base social benchmarking and the $\mathrm{OMC}$, if it suggests that common objectives can be used as the basis for the benchmarking process. Instead, we argued that social benchmarking must in general be "bottom-up". Failure to recognise 
this difference would pose a number of dangers. On the one hand, it could bring the $\mathrm{EU}$ institutions into disrepute with the populations of the various Member States, resentful of European disciplines whose rationale they doubt. Equally, the EMU paradigm makes it more likely that European social objectives will be defined by relation to fiscal goals and the requirements of market competitiveness, rather than by reference to social needs: this seems to be a likely consequence of the strong role which the Ecofin Council is playing in the definition of benchmarks. The principal political actors who are driving the OMC in the social field seem to be alert to some of these dangers and they are arguably promoting a 'bottom-up' model of social benchmarking, notably in the field of poverty and social exclusion. Nevertheless, the situation is not at all clear and the 'bottom-up' model is evidenced principally by the permissive approach which the supra-national coordination is adopting towards the preparation of the national action plans against poverty and social exclusion (Social Protection Committee, 2001).

Second, we have argued that the OMC raises fundamental questions of governance. Monetary union provides one model of supranational governance, involving the hegemony of the German monetary authorities, but underpinned by strong political leadership in all the participating countries. In the social field in contrast, there is no such hegemonic definition of common goals, nor is there sufficient political commitment across the Member States to create such goals. Rather than being driven by pressures for convergence coming from above, bottom-up social benchmarking requires both for its political legitimation, and for its dynamic to be sustained, that it be accompanied by processes of public scrutiny and debate: pressures for accountability coming from below. This does not mean that political leadership must surrender to populist whim. What it does mean is a high degree of involvement for the public in scrutinising the policy areas which political leaders choose for benchmarking, the best practices which they identify in other Member States, and the efforts which they then make to improve national performance.

In the practical development of the OMC there are plenty of references to the role of the social partners, non-governmental organisations, regional and local authorities (see, for example, Social Protection Committee, 2001). What is less clear, at the present stage, is the form that this role will take and the real, rather than merely symbolic, forms of public scrutiny that will be institutionalised. In the absence of effective scrutiny it will be easy for Member States to make and implement unpopular policies, under the auspices of 
the EU, while themselves avoiding blame. So also, unless there is a substantial level of engagement by other stakeholders, notably those of civil society, the OMC could lead to inaction, given the fairly loose manner in which it allows Member States to select their own policy priorities.

Towards what sort of social Europe might the OMC lead, if it is interpreted and implemented in the form of this 'bottom-up' social benchmarking, drawing its dynamic from the pressures for accountability coming from below, instead of pressures for convergence generated from above? One possibility is a social Europe with only a vague definition of common social goals, but characterised at the national level by rapidly improvement standards of policy performance, based on intensive cross-national benchmarking and policy learning conducted in the full glare of public debate. This might however be a social Europe where, although standards of performance are converging, the detailed policy goals are not. Rather, a lively public debate at local, regional, national and European levels, albeit within limits set by the requirements of single market compatibility, permits communities to develop a range of different welfare futures.

It is, however, at least as likely that pressures for accountability would themselves become pressures for convergence, even in countries where opinion with regard to the EU tends to be less than positive. Public scrutiny would bring to attention not only the technical means that neighbouring countries use for the delivery of social policies, but also the goals that they adopt. 'Spill-over' from these technical comparisons into a convergence of social goals would be likely, but in terms of general public debate and sentiment, rather than being confined of the political and administrative leaders directly involved in the management of EU affairs. Cross-national policy learning involving this wider public is more likely to stimulate political demands for catching up with the best, rather than for pursuing idiosyncratic national welfare strategies. There is a second sort of 'spill-over' that this process could also generate: not only some real convergence in the social goals which local and national communities in the EU embrace, but also in the credibility attaching to the supranational institutions of social Europe themselves. This is because European social benchmarking of the sort envisaged here, if it promotes better domestic governance, would demonstrate powerfully the positive benefits of European integration. Nevertheless, to proceed in this way is likely to require major acts of political leadership by the governments 
of the Member States, not least in regards to the forms of domestic governance over which they currently preside.

\subsection{Theoretical Implications}

The foregoing analysis can, finally, be related to several broader strands of theoretical literature, which illuminate the developments we have traced but which are also themselves placed in a new light.

First, the OMC is a form of policy coordination, albeit one which takes place within a polity endowed with a variety of intergovernmental and supranational modes of decision-making. It can therefore be viewed by reference to the substantial literature on policy coordination. Peters (1998), reviewing the theoretical debates on policy coordination as the product of hierarchy, markets and networks, explores, in particular, the role of networks in policy coordination and the implications for more participatory forms of governance. The distinction we have drawn between "benchmarking from above" and "benchmarking from below" explores the practical dilemmas which organisational coordination poses within the multi-tiered policy-making arena of the EU. Yetit also poses as a question something that Peters tends to take for granted: coordination for what? The Lisbon Summit affirms that a wide range of policies, hitherto protected as national prerogatives, are significant instruments in the drive for a "dynamic knowledge-based economy". Instead, this paper has traced the practical political difficulties in defining common goals in many of these policy areas. We have argued that what is coordinated may be less the policies themselves, than the processes of cross-national benchmarking and organisational learning, by means of which citizens are provided with improved standards of domestic policy performance.

Secondly, our analysis suggests that 'bottom-up' social benchmarking should be conceived not as a looser version of 'top-down' benchmarking, but rather as having a logic of its own: involving decentralised learning networks, driven to a substantial extent by the policy actors in the individual countries. This analysis can, in turn, be related to the larger literature on organisational learning, stressing the role of decentralised learning networks, open to a variety of actors with their distinct agendas, as against traditional models of centre-periphery learning (see Schon, 1971; Room, 1986: Chapter 7; Senge, 
1990). It can also be related to the literature on cross-national policy transfer and lessondrawing (see, for example, Bennett, 1991; D olowitz and March, 1996; Evans and Davies, 1999).

Third, our analysis is relevant to the larger theoretical debate in the international relations literature, as to the indispensability or otherwise of a hegemon for securing international cooperation (Keohane, 1984). We have argued that while the policy coordination of EMU relied on such a hegemon, and while this has in turn bestowed a certain hegemonic role on the Ecofin Council and the Economic Policy Committee, this only risks bringing the $\mathrm{OMC}$ into disrepute in the social area: scrutiny and accountability from below are likely here to be crucial preconditions for the legitimation and sustenance of policy coordination. In the absence of hegemony, this leaves an active role for national and even sub-national actors, in driving the process of social benchmarking across the European Union. Such a role can then, for example, be related to the analysis of twolevel games in the international relations literature (Evans et al, 1993). That literature focuses primarily on the strategies employed by national negotiators in pursuit of international agreements, which then require ratification by domestic constituencies. Here, in contrast, just as important are the strategies of sub-national actors, deploying EU-wide benchmarking and policy comparisons, and perhaps even constructing crossnational alliances with their peers elsewhere, in order to refashion or "recalibrate" national welfare settlements (Ferrera et al, 2000; cf Evans et al, 1993, pp 31-2, 418-423).

Finally, our analysis can be related to the literature on the governance of international and supranational organisations, the EU in particular. Scharpf (1997, Chapter 9) provides a bleak prognosis of the legitimation and govemance problems of the EU. He argues that while actions at European level which are associated with negative integration - the removal of barriers to a common market - can readily be legitimated by reference to the original Treaties, this does not extend to those associated with positive integration, including much of social policy. Legitimation of the latter depends upon an institutional infrastructure of democratic accountability and an EU-wide collective identity, yet these are not in prospect. He concludes that "normatively convincing, practically effective and politically feasible solutions are nowhere in sight" (Scharpf, 1997, p 213). 
Our analysis is more positive. Acknowledging that in the social sphere it is difficult to legitimate common objectives and a system of 'benchmarking from above', we sought to analyse 'bottom-up benchmarking', drawing its dynamic from the pressures for accountability coming from below. We proceeded to argue that such a form of social benchmarking, mediated by the EU, was likely in turn to strengthen the legitimacy of the EU itself; and was likely then to spill over into a real convergence of the social goals to which local and national communities across the EU aspire. This argument is consistent with some of the theoretical and policy debates spawned by the forthcoming White Paper on EU govemance. Lebessis and Paterson (2001), for example, argue that actions at European level which are associated with positive integration require new forms of engagement downwards with civil society. However, as they further argue, such engagement, unless it addresses the unequal capacity of such diverse actors to engage with EU policy-making, will be empty. 


\section{References}

Adema, W. (1998), “Comment mesurer l'effort social de l'Etat?”, L'O bservateur de l'O CD E , No.211, April-May, pp. 20-23.

Bennett, C (1991), 'How States Utilise Foreign Evidence', Journal of Public Policy, 33:4, pp 3154

Berghman, J. (1997), "Social Protection in the European Union" in Bosco, A. and Hutsebaut, M. (eds.), Social Protection in E urope. Facing up to Changes and Challenges, European Trade Union Institute, Brussels.

Biagi, M. (2000), "The Impact of European Employment Strategy on the Role of Labour Law and Industrial Relations", The International Journal of Comparative Labour Law and Industrial Relations, Vol. 16, No.2, Summer 2000, pp.155-173.

Bonvin, J-M. and Burnay, N. (2000) "Le tournant procédural des politiques de l'emploi : des situations nationales contrastées", Recherches sociologiques, No.2.

CEC (1996), Communication from the Commission "Benchmarking the Competitiveness of European Industry", COM (96) 463 of 9 O ctober 1996.

CEC (1997), Communication from the Commission "Benchmarking: implementation of an instrument available to economic actors and public authorities", COM (97) 153 final of 16 April 1997.

CEC (1999) Report from the Commission on the implementation of the Recommendation 92/ 441 of 24 June 1992 on common criteria concerning sufficient resources and social assistance in social protection systems, CO M (98) 774 of 25 January 1999.

CEC (2000a), Report on Social Protection in Europe in 1999 (presented by the Commission), CO M (2000) 163 final, 21 March 2000.

CEC (2000b); Proposal for a decision of the European Parliament and of the Council establishing a programme of Community action to encourage cooperation between Member States to combat social exclusion (presented by the Commission), CO M (2000) 368 final, 16 June 2000.

CEC (2000c), White Paper on Governance "Enhancing Democracy in the European Union", Commission staff working document, SEC (2000) 1545/ 7 final, 11 October 2000.

CEC (2000d), Un Livre blanc sur la gouvernance européenne: "Approfondir la démocratie en Europe", Projet de programme de travail, Communication de Romano Prodi, 16 septembre 2000. 
Council of the European Union (1992a), Council recommendation of 27 July 1992 on the convergence of social protection objectives and policies (92/ 442/ CEE), OJ L245 of 26 August 1992.

Council of the European Union (1992b), Council recommendation of 24 June 1992 on common criteria concerning sufficient resources and social assistance in social protection systems (92/ 441/ CEE), OJ L245 of 26 August 1992.

Council of the European Union (2000), The on-going ex perience of the open method of coordination, Presidency Note, 13 June 2000.

De la Porte, C. (1999a), "Is there an emerging European consensus on social protection?" in G abaglio, E. and Hoffmann, R. (eds.), E uropean Trade U nion Y earbook 1999, European Trade Union Institute, Brussels.

De la Porte, C. (1999b), "The novelty of the place of social protection in the European agenda in 1999 through 'soft law'”, in Barbier, C. and Pochet, P. (coord.), Social D evelopments in the E uropean U nion 1999, Report 67, Observatoire social européen and European Trade Union Institute, Brussels, pp.27-41.

De la Porte, C. (2000) "The instruments of "new governance" for analyses and policymaking in the EU", mimeo, presented at the workshop "New Governance Process in the EU", 12 July 2000, Brussels.

Dolowitz, D and March, D (1996), 'Who Learns What from Whom: A Review of the Policy Transfer Literature', Political Studies, 44: pp 343-357

Dyson, K. and Featherstone, K. (1996), "Italy and EMU as a 'Vincolo Esterno': Empowering the Technocrats, Transforming the State", South E uropean Society and Politics, Vol. 1, No.2, pp.272-299.

Ecofin Council (2000), "Proposal for Structural Indicators", March.

EPC (2000), Report by the Economic Policy Committee to ECOFIN on "Structural Indicators: an Instrument for Better Structural Policies" , 26 O ctober 2000.

ERT (1996), "Benchmarking for policy-makers. The way to competitiveness, growth and job creation", Report by the European Round Table of Industrialists, October.

European Council (2000), Lisbon European Council, Presidency Condusions, 23-24 March 2000.

Evans, M and Davies, J (1999), 'Understanding Policy Transfer: A Multi-Level, MultiDisciplinary Perspective', Public A dministration, Vol 77 no 2, pp 361-383 
Evans, P B, Jacobson, H K and Putnam, R D (eds) (1993), D oubleE dged D iplomacy: International Bargaining and Domestic Politics, University of California Press, Berkeley, California

Fajertag, G. and Pochet, P. (eds.) (2000), Social Pacts in E urope - N ew D ynamics, European Trade Union Institute and Observatoire social européen, Brussels.

Ferrera, M. and Gualmini, E. (1999), Salvati dall'E uropa ?, Il Mulino, Bologna.

Ferrera, M., Hemerijck, A. and Rhodes, M. (2000), The Future of Social E urope. Recasting W ork and $\mathrm{W}$ elfare in the $\mathrm{N}$ ew $\mathrm{E}$ conomy, Celta Editora, O eiras.

Goetschy, J. (1999), "The European Employment Strategy: Genesis and Development", E uropean Journal of Industrial Relations, Vol. 5, No.2, July 1999, pp.117-137.

Goetschy, J. and Pochet, P. (1997), "The Treaty of Amsterdam: a new approach to employment and social affairs?", Transfer, Vol. 3, No.3, pp.607-620.

Kenner, J. (1999), "The EC Employment Title and the 'Third Way': Making Soft Law Work?", The International Journal of Comparative L abour L aw and Industrial Relations, Vol. 15, No.1, pp.33-60.

Keohane, R. (1984), A fter H egemony: Cooperation and D isoord in the W orld Political E conomy, Princeton University Press, Princeton.

Labour and Social Affairs Council (2000), Conclusions of the November Session,

Lebessis, N and Paterson, J (2001), 'D eveloping New Modes of Governance', in O De

Schutter, N Lebessis and J Paterson (eds), G overnanœ in the E uropean U nion, Cahiers of the Forward Studies Unit, Office for Official Publications of the European Communities, Luxembourg.

Leibfried, S. and Pierson, P. (1995), "Semi-Sovereign Welfare States: Social Policy in a Multitiered Europe", in Leibfried, S. and Pierson, P. (eds.), E uropean Social Policy: Between F ragmentation and Integration, The Brookings Institution, Washington DC.

Lundvall, B-A. and Tomlinson, M. (2001), "International Benchmarking as a policy learning tool", in Rodrigues, M. (ed.), Boyer, R., Castells, M., Esping-Andersen, G., Lindley, R., Lundvall, B-A., Soete, L. and Telò, M., The N ew Knowledge E conomy in E urope - A Strategy for International Competitiveness and Social Cohesion, Edward Elgar Publishing, Cheltenham.

Math, A and Pochet, P (2000/ 2001), 'Les Pension en Europe: débats, acteurs et méthode', R evue Belge de Sécurité Sociale, forthcoming

Mosher, J. (2000), "Open method of coordination: Functional and Political Origins", E CSA Review, Vol. 13, No.3. 
Mosley, H. and Mayer, A. (1998), Benchmarking N ational L abour Market Performanoe: A Radar Chart A pproach, Brussels: European Commission

Pearsall, J. (1999), The C oncise 0 x ford E nglish D idionary, $10^{\text {th }}$ edition, Oxford University Press, Oxford.

Peters, G (1998), 'Managing Horizontal Government: The Politics of Coordination', Public A dministration, Vol 76, pp 295-311

Pochet, P. (2001), "Subsidiarité, gouvernance et politique sociale", in Delpérée, F. (ed.), L e principe de subsidiarité, Bruylant, Bruxelles.

Room, G . (1986), Cross-N ational Innovation in Social Poligy, Macmillan, London.

Room, G. (1993), A nti-Poverty A ction-Research in E urope, Bristol: SAUS

Scharpf, F W (1997), G ames Real A ctors Play, Westview Press, Boulder.

Scharpf, F. (2000), "Notes Toward a Theory of Multilevel Governing in Europe", MPIfg D iscussion Paper, No.00/ 5, Max Planck Institute for the Study of Societies, Cologne.

Schon, D . A. (1971), Beyond the Stable State, Norton, New Y ork.

Senge, P. (1990), The Fifth D iscipline, Random Century.

Social Protection Committee (2001), N ational A ction Plans against Poverty and Social E x clusion (N A Psind) 2001/ 03, (Ref:SPC/ 01/ 01/ 02_EN Council Ref:5366/00), Directorate E2 DGH EMPL (J27 1/ 201), Brussels.

Tholoniat, L. (2000), "L'administration française face à la stratégie de l'emploi: jeux de légitimité et enjeux de gouvernance", Paper presented at the colloquium "l'Europe en quête de légitimité", Université libre de Bruxelles, 30 November and 1 D ecember 2000, Brussels.

Tronti, L. (1998), Benchmarking Labour Mark et Performances and Policies 1, http:/ / www.iasberlin.de/ ersep/ imi61_uk/ 00140002.htm

Woolley, J T (1992), "Policy Credibility and European Monetary Institutions", in A M Sbragia (ed), E uropolitics: Institutions and Policy-Making in the "N ew" E uropean Community, The Brookings Institution, Washington DC. 